\title{
Állampolgárok helyett SZURKOLÓK!! A gazdaságvédelmi akcióterv mint politi- kai termék netnográfiai vizsgálata
}

\author{
Honti Tamás \\ Szegedi Tudományegyetem
}

\begin{abstract}
A TANULMÁNY CÉLJA
A tanulmány a COVID-19 járvány következtében bevezetett válságkezelő gazdaságpolitika választói megítélését vizsgálja meg netnográfiai elemzéssel. A Gazdaságvédelmi akcióterv kiszorít minden mást a politikai napirendről, így a 2022-es választást eldöntő politikai téma lehet, ezért a hozzá kapcsolódó attitüdök elemzése kiemelkedően fontos. A kutatás három célt kíván elérni:

1. a választói ítéletalkotás szempontjainak megismerését,

2. választói szerepek alkotását az információfeldolgozás folyamata alapján,

3. a választói értékelések során fellépő kognitív torzítások, heurisztikák feltérképezését.
\end{abstract}

\section{ALKALMAZOTT MÓDSZERTAN}

Magyarország Kormánya Facebook oldal gazdaságpolitikai témájú posztjai közül tíz kép alapú bejegyzés és Orbán Viktor miniszterelnök 2020. április 6-i Gazdaságvédelmi akciótervének videóformátumban történő bejelentése az elemzés tárgya. A netnográfia egyik fő előnye, hogy az állampolgárok első reakcióit vizsgálhatjuk meg a bejegyzésekben $(3300 \mathrm{db})$ és visszatérő sémákat kereshetünk az ítéletalkotás folyamatával kapcsolatban.

\section{LEGFONTOSABB EREDMÉNYEK}

A politikai termékre ajánlatcsomagként tekinthetünk, melynek szakpolitikai, illetve szimbolikus elemei egyaránt lehetnek és elsősorban a politikai napirend segítségével válik megismerhetővé a választók számára. A kutatás feltáró céllal készült és a válságkezelő gazdaságpolitikával kapcsolatos ítéletalkotás szempontjaira fókuszál, illetve az online nyilvánosságban vitázó kommentelők által felvett szerepeket mutatja be. A legfontosabb empirikus eredmény, hogy a pártpreferencia mellett az intézményi bizalomnak kiemelkedő szerepet tulajdoníthatunk a Gazdaságvédelmi akciótervvel kapcsolatos ítéletalkotás során. Nyolc szerepet azonosíthatunk a netnográfiai elemzés segítségével, melyekben a bizalom eltérő szintjeit figyelhetjük meg és különböző heurisztikák kapcsolódhatnak hozzájuk. Összefoglalva a tanulmány bemutatja, hogy a klasszikus demokrácia kompetens, informált és a politika iránt érdeklődő állampolgárából, hogyan válik futball szurkoló a valóságban.

\section{GYAKORLATI JAVASLATOK}

Egy szakpolitika sikeréhez elengedhetetlen az állampolgári bizalom erősítése, amihez a társadalmi megygyőzési folyamat uralása, a benne megjelenő választói szerepek ismerete szükséges. A tudatosan felépített és hosszú távon használt politikai nyelv (framing) képes automatikus választói reakciókat előidézni, ami segít az inkumbens kormány számára az új szakpolitikai intézkedések elfogadtatásában.

Kulcsszavak: politikai marketing, politikai termék, válságkezelő gazdaságpolitika, választói ítéletalkotás

DOI: 10.15170/MM.2021.55.KSZ.01.07 


\section{BEVEZETÉS INTRODUCTION}

A politikai marketing kifejezés 1956-ban született, Stanley Kelly-töl, a Princeton egyetem politológusától származik (Butler \& Harris 2009), de a kilencvenes években indult hódító útjára és terjedt el a tudomány világában, illetve a közbeszédben (Merkovity 2008). Sok teoretikus bizonytalanság és probléma merül fel a politikai marketing értelmezése kapcsán, azonban egy konszenzusos pont létezik a terület kutatói között: a politikai szereplök használják a marketing szemléletmódját és eszközrendszerét (Look \& Harris 1996, Wring 1997, Kiss 2000, Henneberg \& O'Shaughnessy 2007, Merkovity 2008, Orosdy 2010, Harris \& Butler 2012). Az „út keresés fázisa” kifejezéssel jellemezhetjük az utóbbi három évtizedet, amelyben idáig még nem alakult ki egységes kutatói program, megközelítésmód, fogalomrendszer, illetve domináns módszertan. Henneberg és O'Shaughnessy (2007) nagyhatású cikkükben azt állítják, hogy már a marketingen belül is versenyző koncepciókról beszélünk és fragmentáltságról, ami nehezíti a politika piacára történő adaptációt. A 2002-es évet mérföldkőnek nevezhetjük a terület történetében, mivel megszületett az első folyóirata a Journal of Political Marketing.

A kutatás központi kérdése: milyen tényezők alapján itélik meg az állampolgárok a magyar kormány válságkezelö gazdaságpolitikai intézkedéseit?

A tanulmány elöször a politikai termék fogalmának értelmezésével kezdődik, amely révén a választói magatartás iskolái, a demokráciaelméletek és a politikai marketing elmélete segítségével megalkotjuk definíciónkat. Ezután a Gazdaságvédelmi akciótervet mint politikai terméket elemezzük, majd bemutatjuk a netnográfiai kutatás eredményeit, melyben a kommentelők információáramlásban felvett szerepeit és az ítéletalkotás szempontjait vizsgáljuk meg.

\section{A POLITIKAI TERMÉK ÉRTELME- ZÉSE POLITICAL PRODUCT}

Egyes szerzők a politikai terméket a programmal (Newman 2000) azonosítják, mások a jövőképpel (Orosdy 2007), és van, aki az ideológiával (Józsa 2004). Egyes megközelítések szerint a csere tárgya - vagyis a politikai ajánlat - három részből tevődik össze, a politikusból, a pártból és az ideológiából
(Harris \& Butler 2012), illetve van, aki versengő imázsok csatájaként tekint rá (Scammel 2015). A politikai termék definiálását mindannyian központi kérdésnek tartják, sőt a szerzők jelentős része a többi stratégiai terület esetében is törekszik az adaptálásra. Henneberg és O'Shaughnessy (2007) nem ért egyet ezzel a megközelítéssel, elavultnak és naivnak tartja.

A fentieket úgy szintetizálhatjuk, miszerint a politikai termék célja, hogy választ adjon arra a kérdésre, hogy miért szavazzon az állampolgár egy adott jelöltre, pártra. Jelen tanulmányban a politikai terméket mint ajánlatcsomagot értelmezzük, ami szakpolitikákból (Newman 2000) és szimbólumokból (Sears 1993) tevődik össze, amit fogyasztáselméleti analógiával élve akár funkcionális és szimbolikus fogyasztásnak is nevezhetünk. Ezeket a politikai termékeket a politikai napirendi témákon, vagyis az „issue” -kon keresztül észlelik elsősorban a választók (Török 2005), és a habermasi érvelést használva a kommunikáció megfeleltethető a politikai cselekvés egyik formájának (Sas 2016), amit a hatalom megszerzése és megtartása szempontjából a legfontosabbnak tekintek. A megközelítést összegezve a politikai termék koncepció az alábbi feltevésekkel és jellemzőkkel rendelkezik:

- Az issue-voting nemcsak a klasszikus demokrácia modellje szerinti szakpolitikai szavazást jelenti (Downs 1957), hanem szimbolikus szavazást is (Sears 1993).

- A termék egy ajánlatcsomag, ami válaszol „miért szavazzak rá kérdésre?” és szakpolitikai, illetve szimbolikus elemekből áll.

- A termékeket a politikai napirend segítségével ismerik meg a választók.

- A politika szolgáltatás, a politikai termék szolgáltatástermék (Hetesi - Veres 2013).

- A politikus a szolgáltatás nyújtója, aki összeforrhat a párttal, de nem nevezhetö terméknek (Merkovity 2008).

\section{GAZDASÁGVÉDELMI AKCIÓTERV MINT POLITIKAI TERMÉK ECONOMIC PROTECTION ACTION PLAN AS A POLITICAL PRODUCT}

Mivel a politika és a média napirendjének legfontosabb témájáról beszélünk, ami minden mást kiszorít, így arra következtethetünk, hogy a Gazdaságvédelmi akcióterv megítélése a következö év, évek legfontosabb issue-ja lesz. Az első komolyabb gazdaságpolitikai intézkedés kihirdetése a hitelmoratórium bevezetése volt (március 18-án), ezt követte az egészségügyi dolgozók támogatásának 
bejelentése (április 4-én), majd a Gazdaságvédelmi akcióterv kihirdetése (április 6-án), amit egy termékcsomagnak nevezhetünk, mivel több, különböző célcsoportnak szánt terméket is tartalmaz. A következőkben kísérletet teszünk az akcióterv mint politikai termékcsomag egyes termékeinek értékelésére azáltal, hogy a szimbolikus jellemző mennyire domináns benne és a nyilvánosan elérhető közvélemény-kutatási adatok ${ }^{1}$ alapján bemutatjuk, hogyan értékelik az állampolgárok. Szituációspecifikusnak és egyénfüggőnek tekinthetjük, hogy egy szakpolitikai intézkedés bír-e szimbolikus jelentéssel, de az eldönthető, hogy mennyire illeszkedik bele a politikai napirendbe és a kormány által használt politikai nyelv kontextusába.

Komoly szimbolikus töltettel rendelkezik a 13. havi nyugdíj bevezetése, amely egy hatalmas, 2,6 millió foót (ksh.hu, é.n.) tartalmazó csoportot céloz meg és szintén megteremti az összehasonlítás lehetőségét az előző válságot kezelő Gyurcsány-kormánnyal, akik megszüntették. A közvélemény-kutatási adatok alapján a lakosság 72\%-a egyetért az intézkedéssel, azonban meg kell jegyezni, hogy ez az egyik legkevésbé támogatott intézkedés is (Századvég 2020). Az egészségügyi dolgozók támogatását szintén szimbolikus lépésnek tartom, mivel az egyébként is magas társadalmi presztízzsel rendelkező orvosok, illetve a többi egészségügyi dolgozó megítélése a járvány alatt valószínűleg még inkább erősödött a média támogatásával. A kormánypárt reagált erre, megpróbálta kihasználni, hiszen az intézkedés magas elfogadottsággal rendelkezik, a lakosság 84\%-a támogatja. A termék érdekessége, hogy az intézkedés kedvezményezettjei az egészségügyi dolgozók, azonban a célcsoportja az állampolgárok szélesebb rétege. Az egyetemisták nyelvvizsga kedvezménye és a diákhitel felvétel lehetősége már kevésbé ennyire egyértelmü, és kérdéses, hogy kiknek és mekkora segítséget jelent az intézkedés. A hitelmoratórium komoly szimbolikus töltettel rendelkezik és visszahoz egy régi ellenségképet, a bankokat. Az iparágak és a vállalkozások támogatásában találhatjuk a legkevesebb szimbolikus elemet, azonban impliciten felfedezhetjük a munkaalapú társadalom értékét, melynek logikus következménye a munkaadók előnyben részesítése a munkavállalókkal szemben. Az akcióterv érdekesebb vonása, hogy összefüggésbe hozható a gazdasági populizmussal (Győrffy 2007, 2012), más néven „welfare populizmussal” (Körösényi Patkós 2015). Körösényi és Patkós (2015) szerint a „welfare populizmus” a politikai szereplők olyan ígéreteit vagy intézkedéseit jelenti, melyek célja pusztán a támogató bázis növelése, nem pedig a hosszabb távú szakpolitikai megfontolások, sok esetben a hosszú távú szakpolitikai megoldásokkal ellentétesek is lehetnek.

Összeségében azt mondhatjuk, hogy a Gazdaságvédelmi Akcióterv mint termékcsomag egyes intézkedései, egyes csoportok önérdekére jól reflektál és együttvéve, illetve elemenként is komoly szimbolikus töltettel rendelkezik, melyből a munkaalapú társadalom üzenete a leginkább erőteljes. ${ }^{2}$

\section{MÓDSZERTAN METHODOLOGY}

A netnográfiai elemzés feltáró kutatás céljából jól használható és a politikai vélemények, attitüdök, érvelések feltérképezésére rendkívül alkalmas. Olyan kvalitatív technika, amely révén az állampolgárok információfeldolgozási folyamatának jellegzetességei megismerhetőek. A nyilvánosságban zajló párbeszédet látványosan demonstrálja, megmutatja a meggyőzési folyamatban előkerülő érveket és megfigyelhető, hogy a politikai csatározásokban a szereplők által használt érvelés megjelenik a választók körében is az egymással folytatott vita során. Mégis egy korlátozott nyilvánosság elemzéséröl beszélünk ${ }^{3}$, amely természetesen általánosításra nem alkalmas, de nem is ez a célja (Mitev - Dörnyei 2015). Kiemelendő továbbá, hogy az elégedetlenek, kritikusok és panasszal rendelkezők szívesebben kommentelnek és osztják meg gondolataikat egyes kérdésekkel kapcsolatban (Csordás et al. 2018). A módszer „atyja” Kozinets (2006), aki öt szakaszát határozza meg a netnográfiának, az első a kulturális entrée, amely során a közösséget és a részvétel szintjét meghatározza a szerző, majd az adatgyüjtés forrását és az elemzésbe bevonni kívánt tartalmat. Ezután hitelesen és több forrásra alapozva a szerző interpretálja az eredményeket, majd az etikai szabályok átgondolása után a kutatás eredményeit a közösségen is teszteli (Mitev - Dörnyei 2010).

A kutatás során Magyarország Kormánya Facebook oldal gazdaságpolitikai témájú posztjai közül

1 A Századvég egyedüliként hetente több telefonos kérdőíves megkérdezéssel készült közvélemény-kutatást publikál a járvány első hulláma alatt, melyek a kormány intézkedéseinek támogatottságát mérik fel. A Századvég kutatások jelentik az egyetlen nyilvános adatforrást a közvéleményről az egyes kérdések tekintetében.

2 https://www.facebook.com/kormanyzat/photos/a.134933189912743/3662834570455903/?type=3\&theater, letöltés: 2020.04.25 .

3 A korlátozott nyilvánosság azt is jelenti ebben az esetben, hogy az ellenzéki szavazók erőteljesen felülreprezentáltak: http://iranytuintezet.hu/ elemzesek-kutatasok/mind/229-hogy-szavaznanak-az-aktiv-facebook-felhasznalok/, letöltés: 2020.04.25. 
tíz kép alapú bejegyzést és Orbán Viktor miniszterelnök 2020. április 6-i Gazdaságvédelmi akciótervének videóformátumban történő bejelentését vizsgáljuk meg (Melléklet 1. táblázat). A válság alatt megfigyelhető, hogy a kormánynak és a miniszterelnöknek a Facebook egy kiemelt kommunikációs csatornájává vált, olyannyira, hogy több esetben itt jelentek meg elöször hírek és a köztelevízió innen vett át tartalmakat, mint a március 18-i hitelmoratórium bejelentése esetében ${ }^{4}$. Három Facebook oldalt használ a kormány legintenzívebben a bejelentésekre és a vírussal kapcsolatos kommunikációra: Orbán Viktor oldalát, Magyarország Kormánya oldalt és a Koronavírus tájékoztató oldalt. Ezek közül a Magyarország Kormánya oldalt használjuk az elemzésre, mert a legnagyobb aktivitással rendelkező oldal, a leggyorsabban reagál az új intézkedésekre és az egyes politikai termékekről külön-külön is posztol, amely révén meg tudjuk vizsgálni az akcióterv egyes elelmeit egyenként is. Törekedtünk, hogy a mintából kiszürjük a kamuprofilokat, ami a politika esetében még inkább fontos, így a gyanús kommentelök profilját egyenként elemeztük. Minden poszt esetében az első 300 kommentet vizsgáltuk meg, tehát összesen 3300 bejegyzést, ami 1861 külön személytöl származik, akiknek 45\%-a férfi, $55 \%$-a nő.

A kutatás szempontjából a netnográfia egyik fő előnye, hogy az állampolgárok első reakcióit tudjuk megvizsgálni a Gazdaságvédelmi akciótervvel kapcsolatban. Az akcióterv a kihirdetése pillanatában egy információcsomag, melynek a hatásáról empirikus tapasztalatokat a választók csak később fognak szerezni, így a kognitív információfeldolgozás segítségével kell ítéletet hozniuk róla, úgy, hogy az ellenzéki pártok és a különböző médiumok még nem narrálták egyes pontjait. A 3300 bejegyzésben visszatérő sémákat keresünk és az ítéletalkotás folyamatának megnyilvánulásait. A 3300 bejegyzésből 1652-ben azonosíthatunk a megítéléssel kapcsolatos, visszatérő tartalmi elemeket, szempontokat. A megítélés szempontjai lehetnek gyakran ismétlődő vélemények (pl. , Miért kell a nyugdijasokat kiemelten támogatni?’), hasonló reakciók (pl. „Engem miért nem támogatnak?”), vagy akár a személyes értékek kifejeződései is (pl. , Csak azt támogassuk, aki dolgozni akar!’). Az értékelések során a kormány, illetve a politikai rendszer iránti bizalmat központi jelentőségü tényező, így fokozott figyelmet szentelünk neki. A kommentelök által folytatott párbeszédben megfigyelhetőek visszatérő szerepek, melyekhez jellemző érveket, véleményeket tudunk rendelni, ezért a vizsgálat során ezekből a szerepekből indulok ki és a segítségükkel mutatjuk be a megítélés dimenzióit és a politikai rendszer iránti bizalmat. Ez a megközelítés arra is alkalmas, hogy bizonyos visszatérő, az adott szerephez kapcsolódó ítéletalkotási heurisztikákat azonosítsunk. A vizsgálat során nem használunk kvantitatív megközelítést (pl. egyes vélemények darabszáma), mivel az egyes megnyilvánulások, illetve egyes szerepek keveredhetnek egymással egy adott kommentben, így számszerüsítésük áttekinthetetlenné tenné az elemzést, emellett csak olyan szerepeket azonosítottunk, melyek minden posztnál megjelentek.

\section{EREDMÉNYEK RESULTS}

Az ítéletalkotás gyakran a pártpreferencia alapján meghatározottnak tünik, így a kommentelök döntő többsége a Gazdaságvédelmi akciótervet a kormányhoz való viszonyulásuk alapján értékelik. A viszonyulást a pártpreferencián kívül, egy másik tényező is meghatározza, ez pedig a bizalom. A bizalmat Hámori (1998) attitűdként határozza meg, ahol a truster megbízik a trustee-ban, hogy nem használja ki sebezhetőségét és az érdekeinek megfelelöen fog cselekedni (Szabó 2004). Felmerülhet a kérdés, hogy a pártpreferencia és a bizalom két egymástól független változó-e, vagyis létezhet-e olyan állampolgár, aki nem szereti az adott pártot, de megbízik abban, hogy a saját érdekeinek megfelelően fog cselekedni az adott helyzetben. Létezhet ilyen állampolgár és a vírus kezelése és értékelése szempontjából, ez kiemelt fontosságú kérdés. Ezt a feltételezést a netnográfia megerősíti, mivel a jelenség visszatérően felfedezhető a kommentekben:

- „Én is utálom a Fideszt. Nagyon nagyon utálom. De most szerintem is jól kezelik a helyzetet."

- „Nem vagyok Fidesz párti egy percig sem de most a virus alatt szerintem meg tesznek, amit lehet! Az, hogy lopni fognak az sajnos biztos! De legalább legyen a népnek is valami adva!"

Azonban fontos megjegyezni, hogy a kommentek alapján dominánsabbnak tarthatjuk a pártpreferencia és a bizalom közötti kapcsolat feltételezését, vagyis ha valaki szeret egy pártot, akkor meg is bízik benne. Felmerül még kérdésként - de netnográfiai kutatással nem eldönthető, - hogy melyik tényező magyarázza a másikat, a pártpreferencia alapján alakul ki a bizalom vagy a bizalom révén a pártpreferencia. Medve és Boda

4 https://www.facebook.com/orbanviktor/videos/349072369320623/ letöltés: 2020.04.25. 
(2013) kutatásukban az Európai Unió tagországait összehasonlítva arra jutottak, hogy az új demokráciákban a pártpreferencia valóban erösebben befolyásolja az intézményi bizalmat, mint a régi demokráciákban, tehát egyes intézményeket ,átpolitizáltnak" tartanak a választók, emiatt a pártpreferenciájuk alapján ítélik meg őket.

A bizalomnak számtalan megnyilvánulását láthatjuk még a kommentekben, egyesek megkérdőjelezik a kormány jó szándékát, többen a korrupció vádjával illetik őket, míg mások szurkolóként kifejezik támogatásukat. A bizalomhiányának egy látványos megnyilvánulása az összeesküvés-elméletek és álhírek jelenléte, melyekkel viszonylag gyakran, változatos formában találkozhatunk. $\mathrm{Az}$ összeesküvések az információhiányra adott válaszok és kielégítik az állampolgárok magyarázatok iránti igényét (Krekó 2018). Ezek alapján a bizalmat központi dimenzióként kezelhetjük és a következőkben a kommentekben megnyilvánuló bizalmat alapul véve bemutatjuk az online politikai diskurzusban résztvevők szerepeit (1. táblázat):

- A szurkoló bizalma a legmagasabb, ő csupán demonstratívan kifejezi várakozását és pártpreferenciáját a nyilvánosságban, ami a kormánypártok támogatását jelenti. A diskurzusokat gyakran ők nyitják, de a vitákban már nem vesznek részt.

- A racionalizáló szintén kormánypárti kommentelő, ő szívesen bekapcsolódik a vitákba is, de általában megerősítő információkat keres és a kognitív disszonanciát (Festinger 1957) csökkenti a hozzászólással, illetve a pártpreferenciáját erősíti meg. Ehhez az előhívási heurisztikát gyakran használja, illetve a framinget, melynek segítségével a munkalapú társadalom és a segélyezés közötti döntésként fogalmazza meg a gazdaságpolitika központi problémáját.

- Az igazságbirtokos racionálisnak és tapasztalnak gondolja magát. Hiszi, hogy nagyobb tudása van, mint a többi állampolgárnak és kötelessége terjeszteni „tudását”. Ha nem jár sikerrel az érvelés során, akkor gyakran ,agymosottnak” nyilvánítja az ellenfél híveit és kilép a beszélgetésből. Tipikusan a párbeszédet olyan módon lezáró szerepről beszélünk, amely konszenzust nem eredményez.

- A debattőrt a vita élteti és képes akár húsz kommenten keresztül is érvelni, ami gyakran személyeskedésbe csap át és a másik fél értelmiségi képességeinek minősítésébe.

- Az összeesküvő alacsony bizalmi szinttel rendelkezik és nem igazán kötődik egyik párthoz sem. Csak azért folyt bele a párbeszédben, hogy világmagyarázatát demonstratívan kinyilatkoztassa. Elmeséli az összeesküvés-elméletét, ami megmagyarázza a problémák forrását, kijelöli az ellenséget, de vitázni már nem marad.

- Az éjjeliör inkább ellenzéki kommentelő, aki a nyilvánosság felett „őrködik”. A politikai napirendi témák között mindig talál olyat az elérhetőségi heurisztika segítségével, ami hiedelmeit és pártpreferenciáját megerősíti, kötelességének érzi, hogy ezekre mások figyelmét is ráirányítsa.

- Az önérdekkereső a saját hasznossága alapján ítéli meg az intézkedést és számára az egyéni érdek az értékelés kiindulópontja. A gazdasági populizmus miatt dühös lesz, hogy neki nem jár semmi és nem bízik abban, hogy a kormány az érdekeit fogja képviselni. Inkább ellenzéki kommentelö.

- A kiábrándult rendszerkritikus bizalma a legalacsonyabb, már rég csalódott a politikai rendszerben és a politikusokban, így kerüli a politikát. Ha véletlenül belecsöppen egy párbeszédbe depolitikus attitüdjét fejezi ki. 
1. táblázat: A kommentelők által betöltött szerepek a politikai megnyilvánulásokban Table 1. The roles of voters based on the comments

\begin{tabular}{|c|c|c|c|}
\hline Szerep & Jellemző heurisztika & $\begin{array}{l}\text { Bizalmi } \\
\text { szint }\end{array}$ & Idézet \\
\hline Szurkoló & $\begin{array}{l}\text { A szurkolók kifejezik } \\
\text { támogatásukat, bizalmukat } \\
\text { és pártpreferenciájukat. }\end{array}$ & magas & $\begin{array}{l}\text { „Hajrá Orbán Viktor! Ne add fel, csak igy tovább!!!”; } \\
\text { "Ez a Kormány! Libsi tetvek... Gyúrcsányista } \\
\text { férgek... rajta! Lehet mocskoskodni!”" }\end{array}$ \\
\hline $\begin{array}{l}\text { Raciona- } \\
\text { lizáló }\end{array}$ & $\begin{array}{l}\text { Az intézkedések } \\
\text { igazolásához keresnek } \\
\text { megerősítő érveket. } \\
\text { A leggyakoribb érvek } \\
\text { között a baloldali pártok } \\
\text { teljesítményének negatív } \\
\text { értékelését és a munkalapú } \\
\text { társadalom értékével való } \\
\text { azonosulást találhatjuk meg. }\end{array}$ & magas & $\begin{array}{l}\text { „Ha minden polgárnak X összeget utalnak, akkor kettö } \\
\text { hónapon belül összeomlik a költségvetés. Ráadásul a } \\
\text { továbbiakban még mindig munka nélkül maradnának } \\
\text { sokan, és még további segélyezésre sem maradna } \\
\text { lehetöség. Ezért kell a munkáltatókat támogatni.”; } \\
\text { „Az elégedetlenkedöknek mondanám, hogy emlékez- } \\
\text { zenek vissza a többi kormányok ösztönzö csomagjaira! } \\
\text { Csak megszoritásról szóltak, amit valóban az emberek } \\
\text { fizettek meg. Más szóval, elk *rtuk, de ti majd kifizetitek!", }\end{array}$ \\
\hline $\begin{array}{l}\text { Igazság- } \\
\text { birtokos }\end{array}$ & $\begin{array}{l}\text { Úgy gondolja, hogy ismeri } \\
\text { az igazságot és kötelessége } \\
\text { mások felvilágosítása. Ha } \\
\text { ellenkeznek vele, akkor } \\
\text { agymosottnak nyilvánítja } \\
\text { ellenfelét. }\end{array}$ & közepes & $\begin{array}{l}\text { Olaszok is beismerték, hogy elkéstek! Azért tartanak ott } \\
\text { ahol, sajnos! Meg mi is! Amit irtam engem igazol! Buta } \\
\text { embereknek könnyebb támadni! Ide, hát tessék! Kinek } \\
\text { volt igaza! Nekünk! Ennyi! Nincs mit szépiteni! Minden } \\
\text { jót!; } \\
\text { „Oriásit téved. Egyik pártnak sem vagyok elkötelezettje. } \\
\text { Sót. Csak racionálisan gondolkodom, látok, tapasz- } \\
\text { talok"; }\end{array}$ \\
\hline Debattőr & $\begin{array}{l}\text { Nem elégszenek meg egy } \\
\text { hozzászólással, könnyen } \\
\text { bocsátkoznak kommen- } \\
\text { tháborúba. Szenvedélyesek } \\
\text { és gyakran személyesked- } \\
\text { nek. }\end{array}$ & közepes & $\begin{array}{l}\text { „kívánom, hogy élje meg és tudjon a tükörbe nézni } \\
\text { ennyi hazugság után, amit vagy tudatlanságból, vagy } \\
\text { gyülöletböl irr.” } \\
\text {,Elvakult. Csak majd, ha nem lesz, aki a nyugdijat } \\
\text { kitermeli, akkor fog elgondolkodni. Csak személyeskedik, } \\
\text { nincs egyetlen normális érve. Betanult szöveget kántál. } \\
\text { Kár a szóért” }\end{array}$ \\
\hline $\begin{array}{l}\text { Összees- } \\
\text { küvö }\end{array}$ & $\begin{array}{l}\text { Az aktuális témához nem } \\
\text { annyira szólnak hozzá, csak } \\
\text { egy összeesküvés megosz- } \\
\text { tása erejéig vesznek részt a } \\
\text { diskurzusban. }\end{array}$ & alacsony & $\begin{array}{l}\text { „Teljesen mindegy, ha nagy nehezen le is gyözzük a } \\
\text { COVID19-et, Kína piacra dobja pár hónap múlva a } \\
\text { COVID19 S Plus-t. Mindennel igy szokta.” } \\
\text { „miközben MINDENT elkövetnek elfajult nemzettár- } \\
\text { saink-és a brüsszeli vizfej, / a gobáltökével karöltve/ hogy } \\
\text { probléma mentes legyen...szégyen!”” }\end{array}$ \\
\hline Éjjeliőr & $\begin{array}{l}\text { Olyan politikai napirendi } \\
\text { témákra irányítja a figyel- } \\
\text { met, melyek megerósítik } \\
\text { nézeteit. }\end{array}$ & alacsony & $\begin{array}{l}\text { „Az EU-tól kapott milliárdokból neki kellene állni } \\
\text { végre a lakosság vagy a legveszélyeztetettebbek tesz- } \\
\text { telésének......”; } \\
\text { „És hól van a } 2000 \text { milliárd, amit az Uniótól kaptatok?” }\end{array}$ \\
\hline $\begin{array}{l}\text { Önérdek- } \\
\text { kereső }\end{array}$ & $\begin{array}{l}\text { Az intézkedésekkel kapcso- } \\
\text { latban kifejezi csalódottságát } \\
\text { és úgy gondolja a rendszer } \\
\text { magára hagyta. }\end{array}$ & alacsony & $\begin{array}{l}\text { „Ez minden csak nem a munkásember megsegitése! Már } \\
\text { a szavazásra gyúrnak...”; } \\
\text { „A ruházati üzletek kényszeres bezárása a kijárási } \\
\text { korlátozás miatt, illetve a forgalom visszaesése miatt } \\
\text { beleszámít a " röviditett munkavégzésbe"? Mert a } \\
\text { ruhaipar eddig sehol nem szerepelt... pedig dolgoznak } \\
\text { benne jópáran”" }\end{array}$ \\
\hline $\begin{array}{l}\text { Kiábrán- } \\
\text { dult } \\
\text { rendszer- } \\
\text { kritikus }\end{array}$ & $\begin{array}{l}\text { Negatív attitüddel áll a } \\
\text { kormányhoz és a politikai } \\
\text { rendszerhez egyaránt. } \\
\text { Csalódott és kiábrándult. }\end{array}$ & alacsony & $\begin{array}{l}\text { „Én nem pánikolok, Maga bízik a kormányban, én } \\
\text { nem.”; } \\
\text { „Emberek esnek egymásnak. Ez a cél :( Szomorú. Valaki } \\
\text { ir egy értelmes gondolatot, leirja azt, amit lát, tapasztal, } \\
\text { hall, erre ostobázzák. Nevetséges szintre mennek le, } \\
\text { amiböl már sok per indult. (Csak megjegyzem) Nincs } \\
\text { olyan párt ma Magyarországon, amiben hinni tudnék. } \\
\text { Szomorú!” }\end{array}$ \\
\hline
\end{tabular}

Forrás: saját szerkesztés 
A gazdasági populizmusra (13. havi nyugdíj, egészségügyi dolgozók juttatása), adott reakciók különösen érdekesek, mivel az egyik leghatározottabb és leggyakoribb hozzászólás az önérdekkeresőé, aki azt a kérdést teszi fel általában, hogy ö mikor fog támogatásban részesülni, esetleg megkérdőjelezi a támogatás morális alapját, legitimitását. Gyakran megjelenő értékkonfliktus az emberélet fontosságának és a gazdasági következményeknek a szembeállítása. Az egészségügyi dolgozók támogatását érő leggyakoribb kritika az összeg bruttó értékének hangsúlyozása, amit becsapásnak tartanak többen.

Az intézkedések szigorúságának megítélésével kapcsolatban két tábort különböztethetünk meg, akik a járvány jelentőségét csökkentik, így túl szigorúnak tartják a szabályozást, míg talán a többség túl enyhének. Váratlan elemként gyakran visszatért a posztok tartalmához egyáltalán nem kapcsolódó egyházellenesség, melyben a kommentelők az egyház anyagi hozzájárulását követelik a válság megoldásához. Kiemelendő még, hogy az álprofilokra felhívják a figyelmet a kommentelők és „,megbüntetik” a gyanús profilokat: ,, Anikó, látszólag neked. 2 hete gyártott profilnak tünik. de ha nem igy van akkor megkövetlek és nyilvánosan elnézést kérek! Reakcióból itélve tényleg álprofil”.

\section{ÖSSZEGZÉS SUMMARY}

A klasszikus demokráciaelmélet az állampolgárt tájékozottnak, kompetensnek és érdeklődőnek, politikailag aktívnak feltételezi, aki a szakpolitikák megértése után, a saját érdeke szerint alakítja ki ítéletét egyes intézkedésekkel kapcsolatban. Ezzel szemben azt láthatjuk, hogy a választók inkább szurkolóként viselkednek és nem az igazság - ha létezik egyáltalán - megismerésére vágynak az információfeldolgozási folyamat során, hanem a saját igazságuk megerősítésére, a közösségük győzelmére. A tanulmányban amellett érveltünk, hogy a politikai marketing értelmezéséhez nélkülözhetetlen olyan elméleti alapvetések tisztázása, mint az emberkép vagy a politikai termék fogalma. A racionális választás elmélete ignorálja az érzelmek szerepét és az információfeldolgozás során fellépő kognitív korlátokat. Megjegyzendő, hogy a választók vágynak arra, hogy racionálisnak tünjenek, ami lehet az emberi természet sajátja, de a szocializáció során megtanult igény is. Legfontosabb teoretikus eredmény a politikai termék definiálása, melyet ajánlatcsomagként határozhatunk meg, és egyaránt tartalmaz szakpolitikai (policy), illetve szimbolikus (politics) elemeket. A politikai terméket a politikai napirend segítségével ismerhetik meg a választók, így a politikai aktorok érdeke a napirend befolyásolása, ebből következik, hogy a választói magtartás központi kérdése az információfeldolgozás folyamatának megértése.

Legfontosabb empirikus eredményünk a Gazdaságvédelmi akcióterv mint politikai termékkel kapcsolatos választói ítéletalkotás szempontjainak feltárása. A bizalom és a bizalom különböző megnyilvánulásai (pl. összeesküvés-elméletek) alapjaiban befolyásolják - a pártpreferencia mellett - az ítéletalkotást. A bizalom szintje alapján nyolc kommentelö szerepet különíthetünk el, melyek figyelemre méltóak az információfeldolgozás folyamata szempontjából, mivel sajátos attitüd, érvrendszer és sajátos heurisztikák kapcsolódnak hozzájuk. A szerepek megmutatják a politikai diskurzus egyes aspektusait és a csoportos, illetve a társadalmi meggyőzési folyamat jellemzőit illusztrálják. 


\section{MELLÉKLETEK ATTACHMENTS}

1. táblázat: A kommentelők által betöltött szerepek a politikai megnyilvánulásokban

Table 1. The roles of voters based on the comments

\begin{tabular}{|c|c|c|c|}
\hline A poszt tartalma & Dátum & Poszt szövege & $\begin{array}{l}\text { Kedvelések } \\
\text { száma }\end{array}$ \\
\hline Munkahelyteremtés & 2020.05 .03$. & $\begin{array}{l}\text { „Orbán: Annyi munkahelyet fogunk teremteni, } \\
\text { amennyit a vírus elpusztít. Ebben kell az } \\
\text { egység.” }\end{array}$ & 7600 \\
\hline $\begin{array}{l}\text { Egészségügyi dolgozók } \\
\text { támogatása }\end{array}$ & 2020.05 .03 & $\begin{array}{l}\text { „Orbán: Idén minden egészségügyi dolgozónak } \\
500 \text { ezer forintos pluszjuttatást biztosítunk. } \\
\text { Köszönet a helytállásukért!” }\end{array}$ & 18000 \\
\hline $\begin{array}{l}\text { Egészségügyi dolgozók } \\
\text { támogatása }\end{array}$ & 2020.05 .04 & $\begin{array}{l}\text { „Gulyás: A koronavírus megállításáért az } \\
\text { egészségügyben folyó heroikus küzdelem } \\
\text { elismerése a dolgozókénti } 500 \text { ezer forintos } \\
\text { plusz juttatás.” }\end{array}$ & 2500 \\
\hline Díjmentes parkolás & 2020. 05.05. & $\begin{array}{l}\text { „A koronavírus-járvány elleni védekezés } \\
\text { egyik legfontosabb eszköze az emberek } \\
\text { közötti biztonságos távolság fenntartása. Ezért } \\
\text { hétfötől díjmentes lesz a közterületi parkolás } \\
\text { Magyarországon.” }\end{array}$ & 7700 \\
\hline $\begin{array}{l}\text { Gazdaságvédelmi } \\
\text { akcióterv }\end{array}$ & 2020.05 .05 & $\begin{array}{l}\text { „Pénzügyi alap jön létre a járványvédelmi } \\
\text { kiadásokra. A kormány magán kezdte a járvány } \\
\text { miatti takarékosságot.” }\end{array}$ & 4200 \\
\hline $\begin{array}{l}\text { Gazdaságvédelmi } \\
\text { akcióterv }\end{array}$ & 2020.05 .05 . & $\begin{array}{l}\text { „Gyuláys: A kormány intézkedései elegendőek } \\
\text { lesznek ahhoz, hogy fedezzék a koro- } \\
\text { navírus-járvány elleni védekezéshez szükséges } \\
\text { költségeket és a lehető leghamarabb újra } \\
\text { lehessen indítani a gazdaságot.” }\end{array}$ & 1900 \\
\hline $\begin{array}{l}\text { Gazdaságvédelmi } \\
\text { akcióterv }\end{array}$ & 2020.05 .06 & „Itt a gazdaságvédelmi akcióterv.” & 6300 \\
\hline Szabálybetartás & 2020.05 .06 & $\begin{array}{l}\text { „Ismételten kérjük a budapestieket, hogy szig- } \\
\text { orúbban tartsák be a magatartási szabályokat a } \\
\text { járvány lassítása érdekében.” }\end{array}$ & 3100 \\
\hline $\begin{array}{l}\text { Gazdaságvédelmi akció- } \\
\text { terv bejelentése (videó) }\end{array}$ & 2020.05 .06 . & $\begin{array}{l}\text { „Gazdaságvédelmi akcióterv: itt a miniszterel- } \\
\text { nöki bejelentés.” }\end{array}$ & 12000 \\
\hline $\begin{array}{l}\text { Gazdaságvédelmi } \\
\text { akcióterv }\end{array}$ & 2020.05 .07$. & $\begin{array}{l}\text { „Orbán: „Egyszerre kell megküzdenünk a } \\
\text { járvánnyal és a gazdasági következményekkel } \\
\text { is. Menteni az emberéletet és gondoskodni a } \\
\text { jövőről.” }\end{array}$ & 2900 \\
\hline $\begin{array}{l}\text { Gazdaságvédelmi } \\
\text { akcióterv }\end{array}$ & 2020.05 .07 & $\begin{array}{l}\text { „Palkovics: Az új gazdaságvédelmi költségvetés } \\
\text { nem növeli a kitettségünket, nem akarunk } \\
\text { kívülröl segítséget kérni. A saját problémánkat } \\
\text { magunk akarjuk megoldani.” }\end{array}$ & 2100 \\
\hline
\end{tabular}

Forrás: saját szerkesztés 


\section{HIVATKOZÁSOK REFERENCES}

Butler, P. - Harris, P. (2012), "Considerations ont he evolution of political marketing theory", Journal of Political Marketing, 9 (2), 149-164 DOI: 10.1177/1470593109103022

Csordás T.- Markos-Kujbus É. (2018), "Netnográfia - a pozitív és negatív online szájreklám tartalmi tulajdonságai", Replika, 1-2, 185-198 DOI: 10.32564/106-107.11

Csordás T. - Nyirő N. (2012), "Az innovációterjedése, szerepe az innovációelfogadásban - Az okostelefonok és az on-line kollektív intelligencia", Vezetéstudomány, 1, 64-73

Downs, A. (1957), "An economic theory of political action in a democracy", Journal of Political Economy, 65(2), 135-150. DOI: 10.1093/ oxfordhb/9780198717133.013.32

Dörnyei K. - Mitev A. (2010), "Netnográfia avagy on-line-karosszék etnogárfia a marketingkutatásban", Vezetéstudomány, 4, 55-68

Festinger, L. (1957), A kognitív disszonancia elmélete, in: Hunyady Gy. (szerk.), A kognitiv disszonancia elmélete, Budapest: Osiris Kiadó

Győrffy D. (2007), "Társadalmi bizalom és költségvetési hiány", Közgazdasági Szemle, 54(2), 274-290. o.

Győrffy D. (2012), "Intézményi bizalom és a döntések időhorizontja", Közgazdasági Szemle, 59(4), 412.

Hámori, B. (1998), Érzelemgazdaságtan - A közgazdasági elemzés kiterjesztése, Budapest: Kossuth Kiadó

Henneberg, S. C. - O’Shaughnessy, N. (2007), "Theory and concept developement in Political Marketing: Issues and an Agenda", Journal of Political Marketing, 6 (2/3), 5-32 DOI: 10.1300/j199v06n02_02

Hetesi E. - Veres Z. (2013), Nonbusiness marketing, Budapest: Akadémiai Kiadó

Józsa L. (2004), Marketing a politikában, in: Dinya L. Farkas F. - Hetesi E. (szerk): Nonbusiness marketing és menedzsment. Budapest: Akadémiai Kiadó

Kiss B. (2000), "Álláspontok a marketing politikára való alkalmazhatóságáról", Politikatudományi Szemle, 8, 3, 76-90

Kozinets, R. V. (2006), Netnography 2.0. In Handbook Of Qualitative Research Methods, in: Marketing, Russell W. Belk (szerk.). Cheltenham, UK: Edward Elgar Publishing, 129-142.

Körösényi A. - Patkós V. (2015), "Liberális és illiberális populizmus Berlusconi és Orbán politikai vezetése", Politikatudományi Szemle, 24. (2), 29-54

Krekó P. (2018), Tömegparanoia - Az összeesküvés-elméletek és álhírek szociálpszichológiája, Budapest: Athenaeum Kiadó

Look, A. - Harris, P. (1996), "Political marketing - Vive la différence", European Journal of Marketing, 10(10), 21-31 DOI: 10.1108/03090569610149764
Medve-Bálint G. - Boda Zs. (2017), Az egyenlőtlenség és a jövedelem hatása az intézményi bizalomra, in: Boda Zs. (szerk.), Bizalom és közpolitika - Jobban müködnek-e az intézmények, ha biznak bennük? Budapest: Argumentum Kiadó

Merkovity N. (2008), "Politikai kommunikáció és politikai marketing", Politikatudományi Szemle, 17, 4, 77-102

Dörnyei K. - Mitev A. (2010), "Netnográfia avagy on-line-karosszék etnogárfia a marketingkutatásban", Vezetéstudomány, (4) 55-68

Mitev A. és Dörnyei K. (2015), Netnográfia, in Horváth D. - Mitev A. (szerk.), Alternatív kutatási kézikönyv, Budapest: Alinea Kiadó, 157-185

Newman, B. I. (2000), Politikai marketing, mint kampánystratégia, Budapest: Bagolyvár Könyvkiadó

Orosdy B. (2007), A politikai marketing rendszere, Marketing \& Menedzsment, 41(4-5), 15-23

Orosdy B. (2000), "Politikai marketing, árpolitika, korrupció", Marketing \& Menedzsment, 44, 4, 4-10

Sas G. (2016), Politikai kommunikáció és közösség, Politikatudományi Szemle, 25(1), 29-47.

Scammel, M. (2015), "Politics and Image: the conceptual value of branding", Journal of Political Marketing, 14(1-2), 2-19 DOI:10.1080/15377857.2014 .990829

Sears, D. O. (1993), Szimbolikus politika, Társadalom-lélektani elmélet, in: Hunyady Gy. (szerk.), Történeti és politikai pszichológia Budapest: Osiris Kiadó

Simon, H. A. (1982), Az ésszerüség szerepe az emberi életben, Budapest: Gondolat Kiadói Kör Kft.

Szabó K. (2004), "Az ezerarcú bizalom: a bizalom formáinak fejezete", Szociológiai Szemle, 128-144

Századvég (2020), Koronavírus járvány: A magyarok többsége a gazdaságvédelmi intézkedések mellett áll. 2020. április 11. https://szazadveg.hu/hu/ kutatasok/az-alapitvany-kutatasai/piackutatas-kozvelemeny-kutatas/koronavirus-jarvany-a-magyarok-tobbsege-a-gazdasagvedelmi-intezkedesek-mellett-all, letöltés: 2020.04.25.

Török G. (2005), A politikai napirend, Budapest: Akadémiai Kiadó

Wring, D. (1997), "Reconciling marketing with political science: theories of political marketing", Journal of Marketing Management, 13(7), 651-663 DOI: $10.1080 / 0267257 x .1997 .9964502$ 
Honti Tamás, PhD hallgató honti.tamas@eco.u-szeged.hu

Szegedi Tudományegyetem

\section{CITIZENS OR FANS? NETNOGRAPHIC ANALYSIS ABOUT THE ECONOMY PRO- TECTION ACTION PLAN AS POLITICAL PRODUCT}

\section{THE AIM OF THE PAPER}

The economic policy of the Hungarian government regarding COVID-19 is a political product. It's not moral judgment, it only means the presence of the marketing approach. The aims of this paper are

1. recognition of the attributes of voters judgement,

2. create voters roles based on the information processing,

3. find heuristics and cognitive biases regarding the voters evaluation.

\section{METHODOLOGY}

We conducted a netnographic research about the opinions of voters regarding the economy protection action plan to explore the attributes and dimensions of their judgment. 3300 posts on Facebook page of Hungarian goverment were analyzed and we have been looking for roles, heuristics and the phenomena of trust.

\section{MOST IMPORTANT RESULTS}

The concept of political marketing can explain various political phenomena and political actors use marketing approach and tools to achieve their goals. We introduce our theoretical concept about the political product, which is based on the economic theory of democracy. After that we can identify eight roles based on the netnographic analysis. All in all, we show that the citizen of classic democracy theory, who is competent and well-informed become a football fan.

\section{RECOMMENDATIONS}

The main suggestion of the paper is policy can't be successful without the trust of voters, so the incumbent have to control the social persuasion. Political language is able to evoke automatic cognitive responses, which enhance legitimacy of the policy.

Keywords: political marketing, political product, economic policy, judgment of voters 